\title{
REGULATION 28 OF THE PENSION FUNDS ACT: REGULATING PRUDENTIAL INVESTMENT
}

\author{
By Tshepo Seloane*
}

\section{Introduction}

On 23 February 2011, the Minister of Finance, Pravin Gordhan, announced that there would be changes made to Regulation 28 of the Pension Funds Act (the 1998 regulation). ${ }^{1}$ In terms of this amendment, the objectives of the new regulation would be to ensure that contributions made by South Africans towards their retirement savings would be invested in a prudent manner that would not only protect the investor but would also be geared towards economic growth and development. ${ }^{2}$

The idea of protecting retirement savings was first introduced into South African law in 1962 through the promulgation of Regulation 28 (the 1962 regulation). ${ }^{3}$ Due to vast changes in the market structure at the time, the 1962 regulation had to be revised. The beginning of 1998 saw the updated version of Regulation 28 come into force in terms of Section 36(1)(bB) of the Pension Funds Act. It had therefore undergone a major revision to bring it more in line with other regulations and with the ever-changing investment environment; ${ }^{4}$ but this would not be the only change Regulation 28 would undergo.

\section{The primary aim of Regulation 28}

Regulation 28 was initially created with the primary aim of reducing certain risks, which are inherent in investments. ${ }^{5}$ In order to achieve

Third year BCom LLB student, University of Pretoria.

Act 24 of 1956, thereafter 'the Act'.

Momentum (n.d) 'The Act on regulation 28' https://www.momentum.co.za/for/ you/markets-and-funds/regulation-28 (accessed 27 July 2013).

In terms of GNR 98 in Government Gazette 162 of 26 January 1962.

STANLIB Insights 'Regulation 28 and the RA reason - what to consider' January 2012 http://www.stanlib.com/Insights/012012/regualtion_28_ra.htm (accessed 25 June 2013).

$5 \mathrm{G}$ Gehle 'Where can a member of a retirement annuity fund complain about the benefits and values of the retirement annuity policy on his life?' (2005) 20 Insurance Tax Journal 7. 
this, the regulator would have to impose limits on the investments made to funds. ${ }^{6}$ The intention behind the imposition was to protect funds and their members against imprudent investment decisions because, once the requirement to invest in asset classes (for example debt, property or cash) was complied with, the investor would, for the most part, no longer have protection. ${ }^{7}$

Since 1998, and perhaps even before, the number of retirement fund options, which have become available to investors in collective investment schemes, have become more complicated. The new developments have also caused much instability and confusion for trustees, who generally have no prior investment skills or knowledge of the goings-on in derivatives, structured products and foreign investments. ${ }^{8}$ This lack of skill and training robs trustees of their ability to fulfill their duties. Many of these new types of investment options were not included in the 1998 regulation due to international developments in collective investment scheme structures, which were mainly brought about by the revision of the UCITS III model. ${ }^{9}$ This oversight by the regulator left a significant part of the industry open to abuse. ${ }^{10}$ This was the case in Shabalala $v$ The Grain Industry Provident Fund ${ }^{11}$ where the trustees elected to exercise their common law discretion against the interests of the beneficiary and place the entire fund benefit into trust despite the fact that the complainant was a major. This attempt to exploit the loopholes created by this lacuna had no punishable legal consequences even though it clearly amounted to a conflict of interest.

\section{The need to develop and regulate prudential investment}

Trustees have a number of management functions that need to be carried out and are critical to the execution of their functions or duties. ${ }^{12}$ These functions are more important now than they have

6 National Treasury 'Explanatory memorandum on the final regulation 28 that gives effect to section 36(1)(dB) of the Pension Funds Act 1956' February $2011 \mathrm{ftp}$ : // ftp.fsb.co.za/public/pension/Reg28_EM.pdf_(accessed 27 June 2013).

$7 \quad$ K MacKenzie 'Who will guard the guards?: an appraisal of minors' pension benefits placed into trust income' (2007) 22 Tax, Insurance and Tax Journal 40.

$8 \quad M$ Lowther 'Regulation 28: new challenges for trustees - and the registrar!' Retirement Planning Pensions World Archives, Governance \& Due Diligence June 2011.

9 Although South Africa is not a EU member state, any changes to the UCITS model that affect a trading partner will also have a significant impact on South Africa.

10 that affect a trading partner will also have a significant impact on South Africa. Industrial Law Journal 1849 fn 135.

11 PFA/FS/6784/06/NVC (unreported), determination of the Pension Funds Adjudicator issued on 19 October 2007.

12 M Wierzycka (n.d) 'Be a feature of pension fund investments?'. http://0beta.mylexisnexis.co.za.innopac.up.ac.za/Index.aspx (accessed 25 June 2013). 
been in the past under the 1998 regulation as fund members belong to defined contribution funds in which investment risk is carried directly by members. ${ }^{13}$ In these instances it is the members who carry the risk and as a result, most members will be directly affected by loss, or a lower than average return which is earned by the fund. Currently in South Africa, a plethora of retirement fund options are available for the choosing and the Financial Services Board measures these options in a number of different ways: ${ }^{14}$

- By the size of assets; or

- By the type of fund; or

- By the number of members; or

- By the financial sophistication of trustees and their advisors.

Many trustees are newly appointed and have received only a modest education on their duties. ${ }^{15}$ It was because of this predicament that the regulator was prompted to put systems in place in order to ensure that trustees are adequately guided in the investment of funds. In the end, everyone could agree on the basic premise of the new regulations: Regulation 28 would ensure that investors do not end up investing large portions of their money in complex instruments that they do not understand. ${ }^{16}$

\section{Current position}

The amended Regulation 28 of the Act came into effect on 1 July 2011 with the Financial Services Board (FSB) granting retirement funds a six-month implementation period. ${ }^{17}$ Although this was the case on paper, the changes made by the implementation of regulation 28 only took effect in January and February of 2012. ${ }^{18}$

In order to achieve the objectives set out in the amended regulation, it became important that the regulator impose what it called 'prudent asset diversification principles'. ${ }^{19}$ These principles are stated in general terms: calling for universal compliance with the latstdev.html (accessed 27 June 2013).

Lowther (n 8 above)

Gehle (n 5 above)

Anon 'Managing retirement fund assets - regulation 28 under the spotlight: long term' (2010) 4 Enterprise Risk 18; http://0-search.sabinet.co.za.innopac. up.ac.za/WebZ/images/ejour/sh_eprise/sh_eprise_v4_n6_a9.pdf?sessionid=01-49 569-1865792526\&format $=F$ (accessed 25 June 2013).

17 W Van der Merwe 'Changes to regulation 28 affirm immovable property's place in retirement fund investments' http://www.fedgroup.co.za/pdf/regulatory\% 20developments.pdf (accessed 28 June 2013).

18 STANLIB Insights ( 4 above).

$19 \mathrm{H}$ Victor 'The administrative complexities of member investment choice' Retirement Planning Pensions World, Archives: Trustees' Update September 1998. 
provisions of the Act; ${ }^{20}$ the establishment of an investment policy statement, which is reviewable annually; ${ }^{21}$ and various provisions that deal with the funds and their board members. ${ }^{22}$

The regulator made an immediate effort to come to the rescue of investors by implementing 'percentage limits' that deal with the amount each retirement scheme can invest in each asset class or instrument provided for in the Act. An example of the impact that the limit has had in practice is that retirement funds are no longer permitted to have more than $75 \%$ of total assets invested in equities in terms of the current Regulation. ${ }^{23}$

The current Regulation 28 also regulates all tax incentivised retirement savings, including retirement annuity funds (RA funds), pension funds, provident funds and preservation funds. ${ }^{24}$ It is important to note that endowments and unit trusts - unless they specifically claim to be Regulation 28 compliant - are not regulated by the current Regulation 28. They do, however, still fall under the scope of Collective Investment Schemes Control Act. ${ }^{25}$

\section{The major changes introduced by the current Regulation 28}

The amendment to Regulation 28 preserved some aspects of the 1998 regulation as far as it relates to the narrowly defined pension funds structures. This, however, is not the case as far the broad spectrum of collective investment schemes are concerned of which the following deserve special notice:

(1) Compliance at member level. This means that every member of a retirement fund must be statutorily compliant. Previously only the fund was required to be compliant, which often lead to individual member investments being non-compliant. As the spirit of the legislation is to protect individual members' retirement savings from undue market risks, this loophole has now been closed; ${ }^{26}$

(2) The requirement to perform reasonable due diligence before investing in an asset; 27

This is the first Principle, Regulation 28, subsection 2(a) National Treasury Memorandum.

21 Financial Services Board (n 13 above); H Victor (n 19 above).

22 Financial Services Board (n 13 above); National Treasury (n 6 above); Regulation 28 subsection 2(c).

23 A Swanepoel 'Apportionment of pension fund surpluses' (2002) 17 Income Tax Insurance and Tax Journal 33.

24 National Treasury (n 6 above).

25 Act 45 of 2002.

26 STANLIB Insights (n 4 above).

27 Swanepoel (n 23 above). 
(3) The application of the 'look-through' principle, which involves aggregating a fund's holdings for reporting purposes by including each underlying instrument (with the exception of hedge funds and private equity funds - in other words - guaranteed insurance policies); ${ }^{28}$

(4) Significant changes to respective asset-class limits and groupings. The aim is to encourage diversification among funds through the use of different asset classes, as well as favouring listed instruments over unlisted ones; 29

(5) The entrenchment of the principle that a fund's assets must be appropriate for its liabilities; ${ }^{30}$ and

(6) The requirement that trustees integrate environmental-social governance (ESG) aspects into their investment decision-making process. ${ }^{31}$

\section{Views on the Amendment}

\subsection{Criticism}

Commentary about the new Regulation 28 has been mainly positive, especially from industry players, such as hedge fund managers and private equity funds; perhaps this is influenced by the new 'status of benefit' they acquire under the current Regulation. It is not surprising that the amendment has been lauded almost exclusively from the investment industry. ${ }^{32}$ What remains interesting to note is that there is no standing to speak on behalf of the 7 million or so retirement savers. This of course does not come as a heavy shock, especially when the outcome is a policy document that benefits the industry and government far more than it does those who actually invest. ${ }^{33}$

\subsection{Their concept of 'prudence' does not exist}

The arguments raised are mainly that, despite its claims, Regulation 28 does not set prudent asset limits. ${ }^{34}$ It merely restricts the maximum exposure to each asset class and underlying security, sets minimum limits and diversification principles, ultimately ignoring or failing to protect the retirement fund member. ${ }^{35}$ The resultant effect is as follows:

These fall under the Collective Investment Schemes Control Act.

S Nathan 'What exactly is the point of Regulation 28?' July 2011 http:// www.10x.co.za/blog/what-exactly-is-the-point-of-regulation-28/ 25 June 2013).

As above; STANLIB Insights ( $\mathrm{n} 4$ above)

Nathan (n 29 above); MacKenzie (n 7 above).

Van der Merwe (n 17 above).

Nathan (n 29 above).

Mackenzie (n 7 above).

K Kopke 'A fine balance to avoid overregulation of hedge funds' (2012) De Rebus 43. 
Firstly, the Regulation ignores the investment time factor, as it is not very 'prudent' to hold just one asset class, for example bonds, for any length of time in order to compel someone nearing retirement to invest $75 \%$ in equities or for someone who is a novice to put down $100 \%$ in cash. ${ }^{36}$

Secondly, given the Rand's volatile history, it would not be prudent for the regulator to require a high financial weighting for the elderly who intend on investing in offshore funds (the so called UCITS IV compliant investment vehicles). ${ }^{37}$

Thirdly, the provisions of Regulation 28 do not apply to Government Employees Pension Fund, which is by far the largest pension fund in South Africa; this should have been the Regulation's first start. ${ }^{38}$

Finally, with regards to the trustees, it is submitted that 'prudent' investment is a matter of individual circumstance and professional judgement. Investment and all its labours have always been left to those who have the necessary skill and experience in such matters. ${ }^{39}$ Prudence in such specialised areas of industry thus cannot be based on rules that are imposed upon an industry because no set of rules can be sufficiently wide to encompass all circumstances, especially in a market as volatile as the pension funds market.

It is quite clear that the regulator is still unsure of the trustees' competence to handle the task at hand. The principles, for example, impose a burden upon the fund to invest in the 'education of the board with respect to pension fund investment, governance and other related matters' ${ }^{40}$ Surely the required level of education should be a prerequisite rather than an objective. ${ }^{41}$ This is not immediately evident when one gleans over the provisions of the Explanatory Memorandum. There is seemingly a slight admission by the regulator that there is 'a general lack of investment expertise among trustees, [furthermore] the Regulation remains primarily rule-based' ${ }^{42}$ only affirming the very little faith that the regulator has in the competency levels of trustees.

Investors need trustees who are financially literate. They need trustees who fully understand their responsibility towards the investors, who understand diversification, risk-appropriate investing,

As is usually permitted for cash and government debt.

Undertakings for Collective Investment in Transferable Securities IV as interpreted in sec 65 Collective Investment Schemes Control Act. http://www.gepf.gov.za/index.php/about_us/article/who-is-gepf (accessed 27 July 2013).

39 Portfolio managers or fund managers in terms of the general management collective investment schemes affairs.

40 National Treasury (n 6 above).

41 Nathan (n 29 above).

42 National Treasury (n 6 above). 
different assets and investment products, and the impact of cost and investment styles on the savings outcome. ${ }^{43}$ They need trustees who have strong, well-founded investment beliefs, and who can translate these into an investment policy statement that will help achieve investors' retirement objectives. ${ }^{44}$ Further, they need trustees who act solely in their interest; in other words, they need professional and independent trustees. This aspect has been overlooked many times before and continues to be overlooked by the regulator. It is submitted that the regulation has gone a little too far this time around with an ambitious feat that will do more harm than good because of its impractical considerations.

\section{The way forward}

Unsurprisingly, the new Regulation 28 brings about a reform that has been largely well received by the industry. It does, however, also impose some onerous responsibilities on retirement fund trustees: the regulation requires inter alia that a well-documented, sound process be followed to ensure compliance. ${ }^{45}$ This means that trustees will need to ensure their asset managers have adequate administrative and compliance systems to provide the necessary data and reporting facilities in place within the required time frame and in the prescribed format.

The compliance obligation ensures that asset managers and their clients benefit from the implementation of pre-trade compliance monitoring systems. ${ }^{46}$ These systems allow an asset manager to assess the effect of the proposed 'buy or sell' decision on the total portfolio and how its Regulation 28 status is affected before the trade is executed. ${ }^{47}$ If the trade will result in a breach of the regulation, the trade will subsequently be blocked. Therefore, all asset managers should, in terms of the current regulation, be in a position to acquire similar systems over time. ${ }^{48}$

Where trustees use multiple asset managers, who deal with various collective investment schemes, the services of an asset

Nathan (n 29 above).

Kopke (n 35 above).

S Cranston 'Black Fund Managers: Black Gems' September 2006 http:// free.financialmail.co.za/report06/fmfmsep06/afms.htm (accessed 27 June 2013).

46 STANLIB Insights (n 4 above).

Investment Solutions 'Regulation 28 as it relates to the asset-management industry' April 2012 http://blog.investmentsolutions.co.za/regulation-28-as-it-

48 relates-to-the-asset-management-industry/ (accessed 25 June 2013). Memorandum. Kopke (n 44 above). 
consultant or investment platform may be required to achieve full compliance with the regulation at a total fund level. ${ }^{49}$

\section{Conclusion}

Employed South Africans contribute millions of Rand to different retirement funds annually. Most of these individuals will be completely dependent on this money for subsistence when the time for their retirement comes. It does not come as a huge shock that the measures adopted by Regulation 28 are - although overly ambitious - fundamentally created to protect the interests of these South Africans. It is from the provisions of the Regulation that the intention of the legislature to ensure that no irresponsible trading by asset managers or the abandonment of fiduciary duties by trustees is to be tolerated.

If government is serious about regulating the retirement industry, it needs to address the concerns raised and driven by investor needs, and not those raised by the policy objectives of government and industry. It needs to direct the appointment of trustees in order to safeguard the best interest of investors. Finally, the main focus should be on the most vulnerable in our country - the poor. The needs of the poor can be addressed more efficiently by inculcating a culture of saving at the earlier stages of life, not only through mechanisms of asset allocation. 